\title{
Maize Value Chain for Food Security and Poverty Reduction in Bungoma County, Kenya
}

\author{
Caroline Netia A. Kamau ${ }^{1}$ and Humphrey Wanjala Nyongesa ${ }^{2}$ \\ ${ }^{l}$ Department of Disaster Management and Sustainable Development, Masinde Muliro University of Science and \\ Technology, Kakamega, Kenya \\ ${ }^{2}$ Department of Sugar Technology, Masinde Muliro University of Science and Technology, Kakamega, Kenya
}

\begin{abstract}
Worldwide, $75 \%$ of the people lack adequate food while $47 \%$ in Kenya and $70 \%$ in Bungoma County are food insecure. Kenya has applied agricultural extension approaches to enhance food security and poverty reduction but to little avail due to their concentration on increasing agricultural production. This calls for an alternative approach that emphasizes agricultural innovation systems that enhance land productivity and increased incomes. The objective of this research was to establish the importance of value chain approach to food security and poverty reduction in Bungoma County. The research design was triangulated and crosssectional survey. Purposive, stratified and simple random sampling strategies were used to give a sample size of 347 out of 65,707 maize value chain smallholders. Data collection instruments included; questionnaires focus group discussions and key informants. Descriptive and inferential statistical analysis was used to analyse data. The research revealed that the degree of development of the maize value chain in Bungoma County is as low as $31 \%$ indicating that there is limited capacity for identifying challenges and their solutions as well as identifying investment opportunities vertically and horizontally along the chain. Based on the study findings, it is recommend that the maize value chain players should be mobilized and sensitized on the needs of maize value chain development
\end{abstract}

Keywords: Maize Value Chain, Food Security

\section{Introduction}

World food situation is that 842 million people in the world are food insecure with $75 \%$ of found in the rural and developing countries [1]. Although, agriculture remains the mainstay of Kenya's economic development, food security and poverty reduction are still major challenges for Kenyan Government as $47 \%$ of its rural population is food insecure [2]. Subsequently, Bungoma County like most of Kenyan counties depends on agriculture for its livelihood. It suffers from chronic and sometimes severe food insecurity (70\%) and high level of well spread poverty which looms at $3.79 \%$ poverty index meaning that $53 \%$ of Bungoma population is poor (Economic Survey Report, 2014). It is the fourth poorest county in Kenya after Kakamega \& Mandera (4.69), Turkana [3]; [4] and Nairobi (3.94) that have the given respective poverty indices. Studies reveal that agribusiness and value chain approach have great potential for enhancing land productivity and increased incomes which can motivate increased food production and consumption through increased inclusive growth, mitigation of prices and weather shocks, reduced post-harvest handling wastes, and increased business opportunities [3]; [4].

Bungoma County is one of the four counties which together produce $45 \%$ of the maize produced in Kenya. The other three counties are Narok, Uasin Gishu and Trans Nzoia [5]. Maize crop covers 95\% of the land under food crop production and $80 \%$ of the value of food crops produced annually in Bungoma County, especially, in Tongaren, Kimilili, Mt. Elgon and Sirisia sub counties. This is the crop that determines not only the food security of the county and the Kenyan nation by extension, but also the earnings in the agricultural sector on which three quarters of the country's population is dependent on for their livelihood [3]; [4].Therefore, focusing on food security in Bungoma County is synonymous with focusing on maize. However, although maize production in the county has been on an upward trend over the last years increasing at an annual average rate of about $9.7 \%$ in the County, it is still not sufficient as per capita consumption is around 1.5 bags of 90kgs making the annual consumption requirement to be 3,737,690 bags, while production is at 2, 962,830bags $(98,761 \mathrm{Ha})(6)$. Due to this deficit, the county has to rely on imports from neighbouring counties like Trans Nzoia, Uasin Gishu and countries like Uganda worsening the food accessibility issues [6]. This has led to chronic and sometimes severe food insecurity (70\%) and high level of well spread poverty (53\%), exhibiting a poverty index of $3.79 \%$ being the fourth contributor of poverty in the Kenya [3].

Bungoma County like the rest of Kenya has used various agricultural extension approaches like NAEP, T\&V, NALEP, and FFS since 1982, to help enhance food security and poverty reduction [9]; [10], but to no much avail mainly due to their emphasis towards increasing agricultural production using conventional agricultural methods with little focus on agribusiness [11]. Although value chain approach is sensitive to 
resource scarcity, business environment and climate change, as a model of agribusiness, it has the potential to enhance food security and create opportunities for raising incomes for the world's poor, three-quarters of whom live in rural areas, as revealed by [12]; [13]. Consequently, this study was set out to establish if adopting value chain approach shall enhance maize production, marketing and consumption thus improving food security, poverty reduction and mitigation of climate change.

\subsection{Study Site and Population}

\section{Study Methodology}

The study was undertaken in two Sub Counties; Sirisia and Tongaren, of Bungoma County in Kenya as indicated in Fig 1 below with the study population of 65,707 people that were composed of input suppliers, producers /farmers, transporters, processor, traders, maize value supporters and the chain enablers.

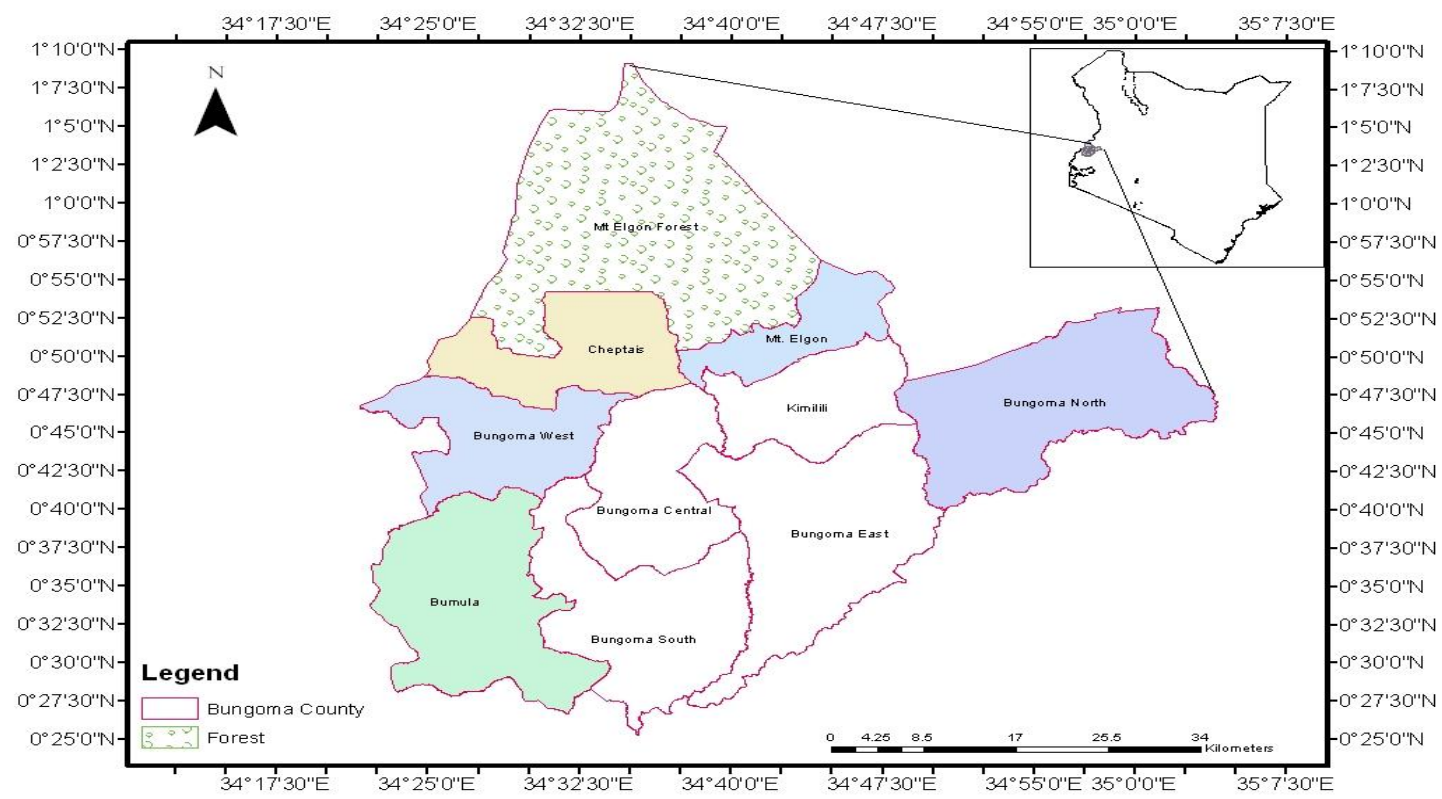

Figure 1: Map of Bungoma County: (Source: BCIDP, 2013)

\subsection{Study Procedure}

The research methods used were secondary data collection whereby archival sources GOK reports, journals, internet websites and books were reviewed. Primary data collection method was also to gather data from the field using tools like questionnaires, focus group discussions (FGDs), key Informants, interviews and observations. They helped obtain information relevant to the research problem, specify the type of evidence needed to accurately describe and assess meaning related to an observable phenomenon. A study sample of 347 was obtained using this formula or equation; $\mathbf{n}=\mathbf{N} / \mathbf{1}+\mathbf{N e}^{2}$, was used for large units of observation and purposive sampling and census for small units. Where $\mathrm{n}$ is the sample size required, $\mathrm{N}$ is the population size of the target value chain players in the study area and e is the level of precision that is assumed to be about 0.05 .

\section{Results and Discussion}

\subsection{Level of Maize value chain Development in Bungoma County}

The study sought to establish the level of development of the maize value chain or how productive is the maize business as the major source of livelihood in Bungoma County by investigating the key maize value chain category actors on the knowledge of importance of maize crop, maize businesses, maize value chain collaborators and stakeholders, benefits for the value chain players, challenges and proposals for the chain improvement. This process of investigating the chain can also be known as mapping of the value chain whereby the findings on the respondents per category were as follows;

\subsection{Input Suppliers for maize farm inputs}


These are the maize farm inputs businesses that supply, distribute, stock and dispense inputs like hoes, fertilizers, seed and agro-chemicals. From the respondents the study sought to know what type of farm inputs are supplied in the study area and Fig 2 portrays the findings;

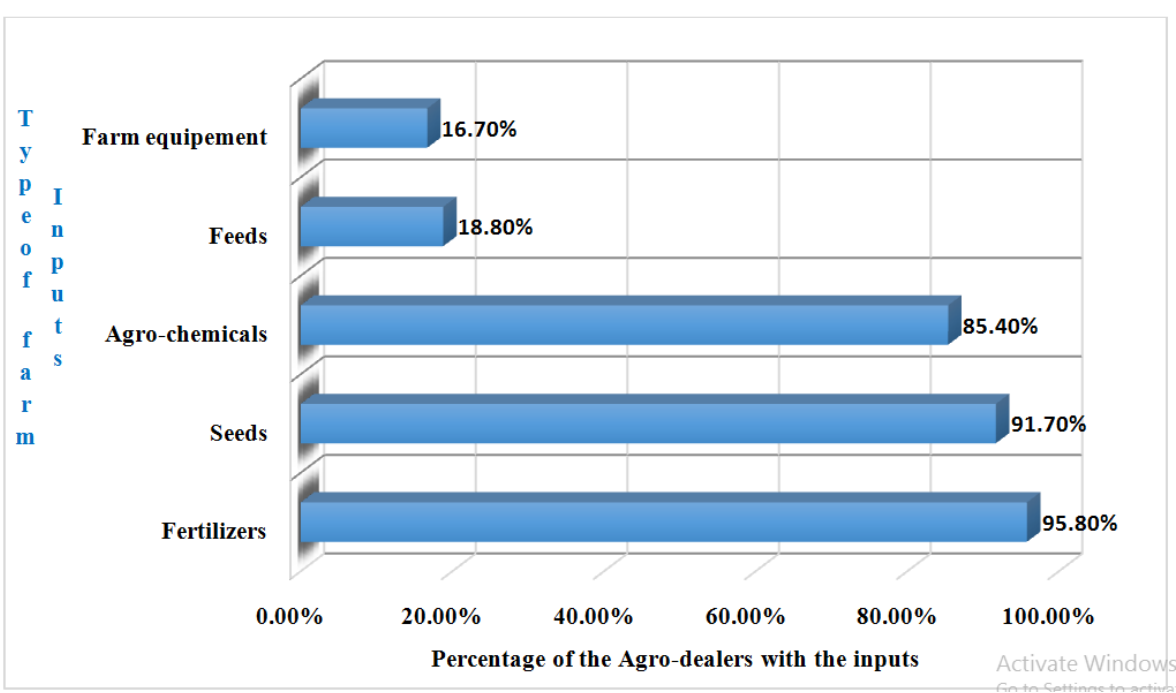

Figure 2: Main farm inputs supplied by the dealers in the study area

Fertilizers, seeds and Agro-chemicals are the farm inputs that are largely supplied or stocked as shown in Fig 2. above while feeds and farm equipment are less stocked or supplied in the region (18.8\% and $16.7 \%$ respectively) thus a clear indicator of deficiency in the supplying of basic farm inputs like ploughs, planters, tractors, shellers, tarpaulins, etc. leading to ineffectively done farm operations contributing to the low yields witnessed.

\subsection{Knowledgeable of the agro-dealers in their business development}

From the 48 agro-dealer respondents interviewed, the study sought to establish the proportion of them that were knowledgeable in their business in relation to the maize value chain development and table1 displays the results;

Table 1: Proportion of the Agro-Dealers Knowledgeable in the Business

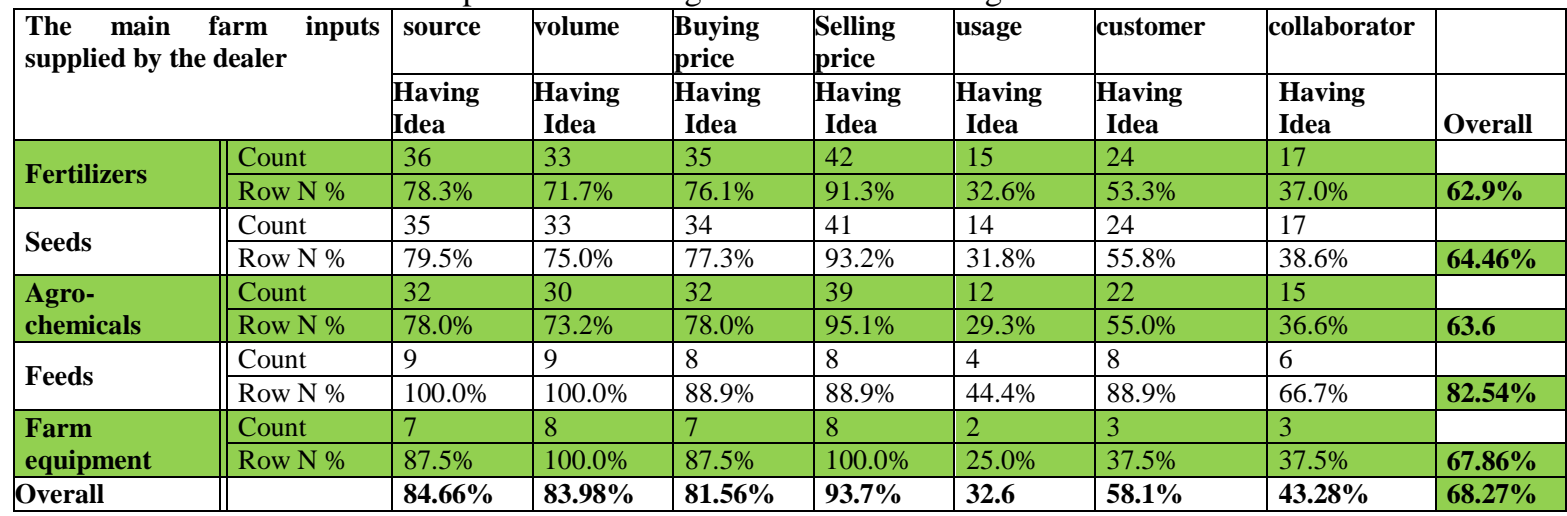

For development of the maize value chain it is essential the input suppliers are knowledgeable, especially, in the usage, market and collaborators in the farm inputs they deal in. Table 1 above indicates that only $32.6 \%$ have knowledge on how to use the products they are dealing with, $58.1 \%$ dealers understand the market (customers) for their products and only 43, $28 \%$ know who to collaborate with or the other stakeholders. This finding implies that the chain development amongst the farm input suppliers is at an average of $44 \%$. It is also a clear indication that the input suppliers need a lot of capacity building in the business of maize input supplying and maize value chain development since they are key to maize production and productivity.

\subsection{Importance of agro input supplying business in the study area}

The study sought to know how important the agro input supplying business is in the region by interviewing the sampled input suppliers on their business registration status. The following Fig 3 below displays the results; 


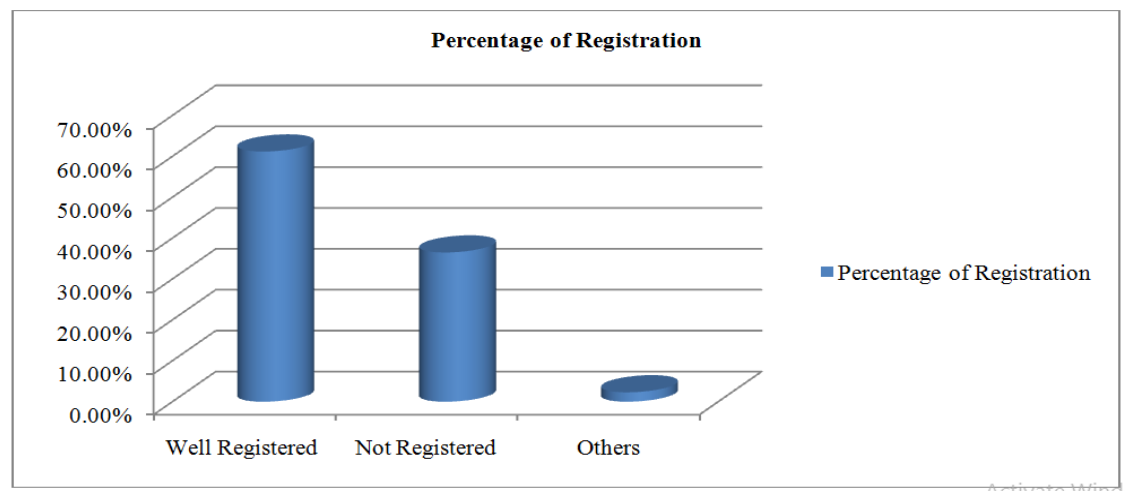

Figure 3: Percentage of Registered Maize businesses

The results show that only $61.2 \%$ of the 48 input suppliers sampled in the study area were well registered, 36.5\% were not registered and 2.3\% seasonal or convenient input supplying as shown in Fig 3 above. This means that the agro-input supplying business is not taken seriously in the county as the agro-stockiest lack the discipline, ethics and adequate competence required for the serious business of developing the maize value chain (36.5\% dispensing farm inputs without required business permits).

\subsection{Type of Agro-Input Businesses found in the study area}

Information from the respondents and observation yielded the results displayed in the following Table 2.

Table 2: Type of Agro-Input Businesses found in the study area

\begin{tabular}{|c|c|c|c|c|c|c|c|c|}
\hline \multirow{2}{*}{\multicolumn{2}{|c|}{ Nature of the business }} & \multicolumn{4}{|c|}{ Position in the business } & \multicolumn{3}{|c|}{$\begin{array}{l}\text { Seasons that the dealer operates farm } \\
\text { inputs business }\end{array}$} \\
\hline & & Owner & Employee & Child & Total & $\begin{array}{l}\text { Throughout } \\
\text { the year }\end{array}$ & \begin{tabular}{|l|l|} 
Long rain \\
season
\end{tabular} & Total \\
\hline \multirow{3}{*}{ Wholesale } & Count & 6 & 0 & 0 & 6 & 6 & 0 & 6 \\
\hline & Row N \% & $100.0 \%$ & $0.0 \%$ & $0.0 \%$ & $100.0 \%$ & $100.0 \%$ & $0.0 \%$ & $100.0 \%$ \\
\hline & Column N \% & $15.8 \%$ & $0.0 \%$ & $0.0 \%$ & $12.5 \%$ & $17.1 \%$ & $0.0 \%$ & $12.5 \%$ \\
\hline \multirow{3}{*}{$\begin{array}{l}\text { Small Retail } \\
\text { Shops }\end{array}$} & Count & 32 & 8 & 2 & 42 & 29 & 13 & 42 \\
\hline & Row N \% & $76.2 \%$ & $19.0 \%$ & $4.8 \%$ & $100.0 \%$ & $69.0 \%$ & $31.0 \%$ & $100.0 \%$ \\
\hline & Column N\% & $84.2 \%$ & $100.0 \%$ & $100.0 \%$ & $87.5 \%$ & $82.9 \%$ & $100.0 \%$ & $87.5 \%$ \\
\hline \multirow{2}{*}{ Total } & Count & 38 & 8 & 2 & 48 & 35 & 13 & 48 \\
\hline & Row N \% & $79.2 \%$ & $16.7 \%$ & $4.2 \%$ & $100.0 \%$ & $72.9 \%$ & $27.1 \%$ & $100.0 \%$ \\
\hline
\end{tabular}

The study results show that $87.5 \%$ of the maize inputs businesses are small retail shops of which some are seasonal $(31 \%)$ and are self or Child operated (76.2\% and $4.8 \%$ respectively). This indicates that the supply and availability of farm inputs is at very low level, unreliable, inefficient and unsustainable calling for more stakeholders and partnerships to invest in the value chain in order to enable farmers to effectively access as required. The Table 2 above further shows the type of agro-input supplying business that is carried out in the county emphasizing the large percentage count of small retail shops (87\%) against whole sale shops (12\%).

\subsection{Major Challenges facing Farm Input supplying Business in the County}

The sampled agro-dealers were asked if they faced any challenges in their business of supplying farm inputs to the maize producers and other stakeholders and the following Fig 4 below portrays their responses or findings.

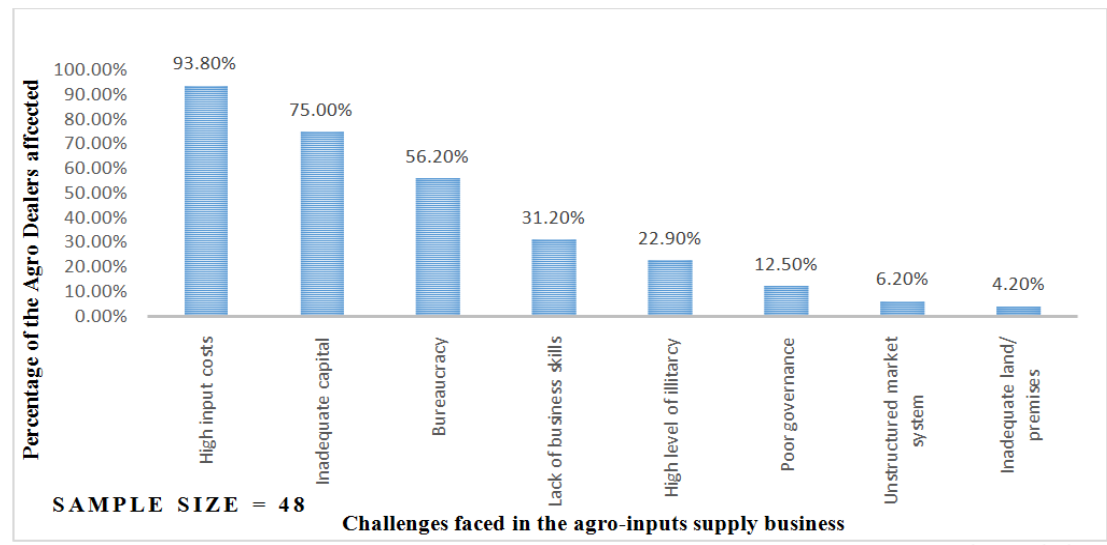

Figure 4: Main Challenges faced in the agro-inputs supply business 
Fig 4 above portrays that high input costs (93.8\%), inadequate capital (75\%), Bureaucracy (56.2\%) and lack of business skills $(31.2 \%)$ are the major challenges that majority of the farm input dealers in the region are facing in their businesses. This calls for the governments to look into how the cost of farm inputs and cost of production could be brought down, promotion of financial inclusion measures, capacity building of agro-dealers in business skills and more stakeholders and partnerships to invest in the value chain in order to enhance business along the chain.

Fig 4 above also portrayed that small retail agro-dealers make $87.5 \%$ of the business implying that there is serious challenge of inadequate funds and poor supplying of inputs to the maize producers. A binary logistic regression was carried out to test on which challenges contributes to most agro-dealers opting for small retail shops in the region and the results were as follows:- The Omnibus Tests of Model Coefficientsindicated a positive value $\left(x_{(6)}^{2}=13.2\right)$ concurring with thePearson Chi-Square $(p=0.04<0.05)$ when ran on the alleged key challenges against type of the input business by use of SPSS computer programme. These indicate that there is significant relationship and indeed these challenges affect the agro-inputs business in the region. Further, using the challenges as the predictor variables in the Omnibus Test of Model Coefficients portrayed positive coefficients $(\boldsymbol{B}=29.996$ and $\boldsymbol{B}=54.688)$ for poor governance and lack of business skills respectively as the key challenges affecting farm inputs business in Bungoma county as shown in table 3 below;

Table 3: variables in the equation

\begin{tabular}{|c|c|c|c|c|c|c|c|c|}
\hline \multirow{2}{*}{$\begin{array}{l}\text { Challenges } \\
\text { variables) }\end{array}$} & \multirow[t]{2}{*}{ B } & \multirow[t]{2}{*}{ S.E. } & \multirow[t]{2}{*}{ Wald } & \multirow[t]{2}{*}{ df } & \multirow[t]{2}{*}{ Sig. } & \multirow[t]{2}{*}{$\operatorname{Exp}(B)$} & \multicolumn{2}{|c|}{$95 \%$ C.I. for $\operatorname{EXP}(B)$} \\
\hline & & & & & & & Lower & Upper \\
\hline Bureaucracy & -25.787 & 889552.565 & .000 & 1 & 1.000 & .000 & .000 & \\
\hline Lack of Business skills & 54.688 & 1778929.176 & .000 & 1 & 1.000 & $2.279 \mathrm{E}+31$ & .000 & . \\
\hline High Input cost & -59.356 & 3537498.678 & .000 & 1 & 1.000 & .000 & .000 & . \\
\hline Inadequate capital & -28.320 & 1579470.851 & .000 & 1 & 1.000 & .000 & .000 & . \\
\hline High level of Illiteracy & -56.122 & 1813708.256 & .000 & 1 & 1.000 & .000 & .000 & . \\
\hline Poor Governance & 29.996 & 3015779.455 & .000 & 1 & 1.000 & $6.236 \mathrm{E}+11$ & .000 & \\
\hline Constant & 115.073 & 4560084.446 & .000 & 1 & 1.000 & $9.449 \mathrm{E}+049$ & & \\
\hline
\end{tabular}

\subsection{Maize Production against other field crops}

Production is a very key segment or section of the maize value chain which in this case consists of maize farmers. The study managed to engage 47 individual farmers and 180 through FGDs from whom it sought to establish the importance of the maize crop to the people of Bungoma by interviewing the respondents on type of crop production in the area, the uses of the maize crop, where maize sold, maize value addition and maize production challenges faced by maize farmers. The findings are shown in the Table 4 below;

Table 4: Type of Farming in the study area

\begin{tabular}{|c|c|c|c|c|c|c|c|}
\hline Crop & $\begin{array}{l}\text { Producers } \\
(\%)\end{array}$ & $\begin{array}{l}\text { Average } \\
\text { farm size }\end{array}$ & $\begin{array}{l}\text { Average } \\
\text { Yield } \\
\text { (Bags/Acre) }\end{array}$ & $\begin{array}{ll}\text { Use } & \text { of } \\
\text { Certified } & \\
\text { Inputs }(\%) & \\
\end{array}$ & $\begin{array}{l}\text { Use of } \\
\text { Extension } \\
\text { Services (\%) }\end{array}$ & $\begin{array}{l}\text { Use of Bank } \\
\text { Loans } \quad \text { and } \\
\text { Insurance }(\%)\end{array}$ & $\begin{array}{l}\text { Those who } \\
\text { sell produce } \\
(\%)\end{array}$ \\
\hline Maize & 86 & 2.75 & 9.8 & 22 & 12 & 1.8 & $76 \%$ \\
\hline $\begin{array}{l}\text { Other } \\
\text { Crops }\end{array}$ & 5.3 & 1.55 & 1.2 & 11 & 1.5 & 0 & \\
\hline
\end{tabular}

The study revealed that $86 \%$ of the farmers had maize as their major crop while $8.8 \%$ grew beans and $5.3 \%$ grew other crops. It also revealed that the average acreage of the farm sizes is 2 acres with an average production of $9.8 \mathrm{bags} /$ Acre. Table 4 also portrays that only $22 \%$ use certified fertilizers and seeds and only $12 \%$ of the farmers receive agricultural extension services while $1.8 \%$ use bank services. It is also shown that $76 \%$ of farmers sell their produce. All these indicate that most of maize farming in the region is done on small scale, subsistence level whereby farmers produce food for home self-sufficiency using mostly own generated agricultural inputs that include seed, fertilizer, labour and capital [14]. This could be as a result of the low percentage of the agricultural extension services received (12\%), lack of funds, low level of education (Primary level - Table 4$)$ of the women who are the majority of the farmers $(60 \%)$ as indicated in Table 4 above. 


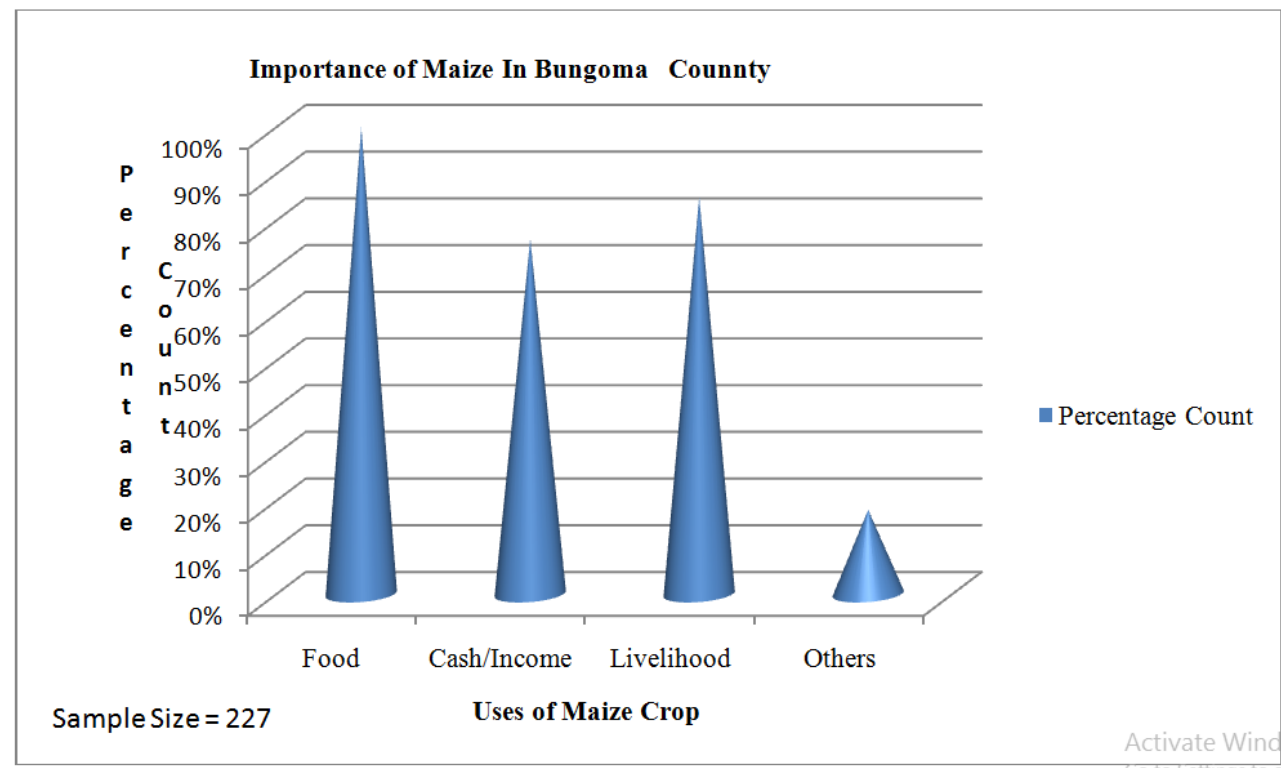

Figure 5: Importance and uses of Maize in Bungoma County

The Fig. 5 above shows that $100 \%$ percent of the respondents depend on maize for food, $76 \%$ for income, $85 \%$ for employment and $18 \%$ for other uses like animal feed. This simply means that maize crop is essential to the lives of the Bungoma population.

\subsection{Maize Producers' Markets in Bungoma County}

Of the 227 producers sampled, the study sought to know where they sold their produce and who are their main buyers since 76\% (Table 5) of them sold maize. Table 6 and Fig. 6 indicate the findings;

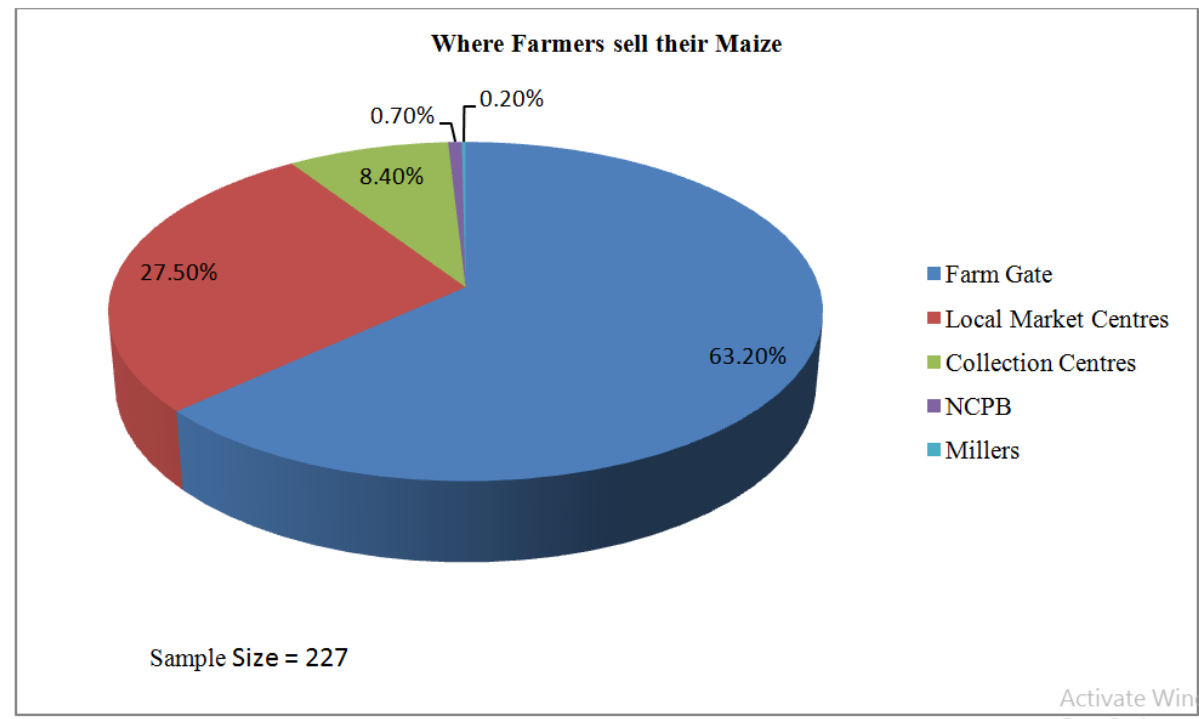

Figure 6: Where Farmers Sell Maize

From the 227 producers sampled, 63.2\% sell their maize at farm gate with the main buyers being brokers, $27.5 \%$ take their maize to market centers where they sell to brokers and local consumers, $8.4 \%$ of them collect their maize collection points to sell through organized organizations like WFP and CBOs like Naima Marketing Self Help CBO in Tongaren. The study also revealed that the main marketing center for farm produce is Chwele Market (82.5\% response), millers and NCPB are sold to at very low percentages $(0.2 \%$ and $0.7 \%$ respectively) and most maize is sold through brokers $(90.7 \%)$. Further, as shown in table 8 bellow, the major maize value addition activities farmers engage in are drying winnowing, sorting and storage. 
Table 5: major value addition by farmers as players in the Maize Value Chain

\begin{tabular}{|l|l|l|l|l|l|l|l|}
\hline & $\begin{array}{l}\text { Drying } \\
\text { \&winnowing }\end{array}$ & Sorting & Storage & cleaning & $\begin{array}{l}\text { Processing/Milli } \\
\text { ng }\end{array}$ & Packaging & $\begin{array}{l}\text { Other } \\
\text { additions }\end{array}$ \\
\hline Count & 47 & 30 & 13 & 4 & 0 & 0 & 2 \\
\hline Percentage & $82.5 \%$ & $52.6 \%$ & $22.8 \%$ & $7.0 \%$ & $0.0 \%$ & $0.0 \%$ & $3.5 \%$ \\
\hline
\end{tabular}

From table 5 above it is clear that none of the farmers in the region take part in processing and packaging of the maize.

\subsection{Major challenges facing Maize farmers as Maize Value Chain players in Bungoma County}

From the respondents the study sought information to establish what challenges face farmers as one of the key maize value chain players in the region and Fig 7 below represents the findings;

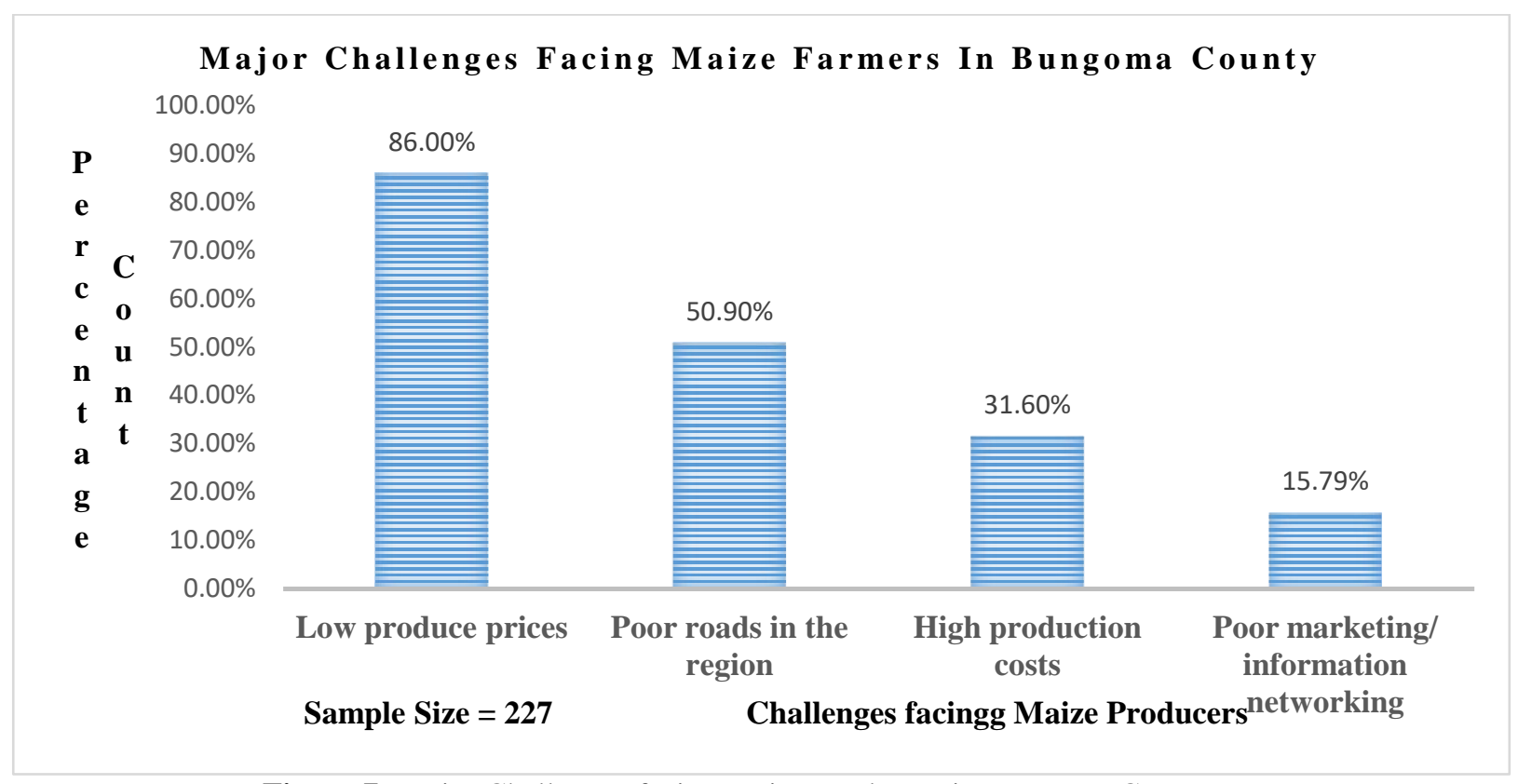

Figure 7: Major Challenges facing Maize Producers in Bungoma County

The findings show Low produce prices $(86 \%)$, poor rural roads $(50.9 \%)$ high farm input prices $(31.6 \%)$, and poor market information $(15.8 \%)$ are the major challenges facing the maize farmers in Bungoma County. These findings are supported by those of (15) who researched on what influences maize production in Bungoma Central

\subsection{Traders in the maize value chain}

The trader category of the maize value chain comprised of both maize transporters and maize traders in the market who formed a sample of 34. The study findings revealed that there are no special transporters for maize produce in the region but instead the ones used are those that transport anything else. These transporters mainly consist of (85.29\%) "Boda-Boda" (bicycles and motor cycles) and $14.71 \%$ pick-Ups and Lorries. They are used to move produce from farm gates, Collection centers, and Market centers to other destinations. Figure 9 depict what percentage of maize is moved to which destinations by transporters; 


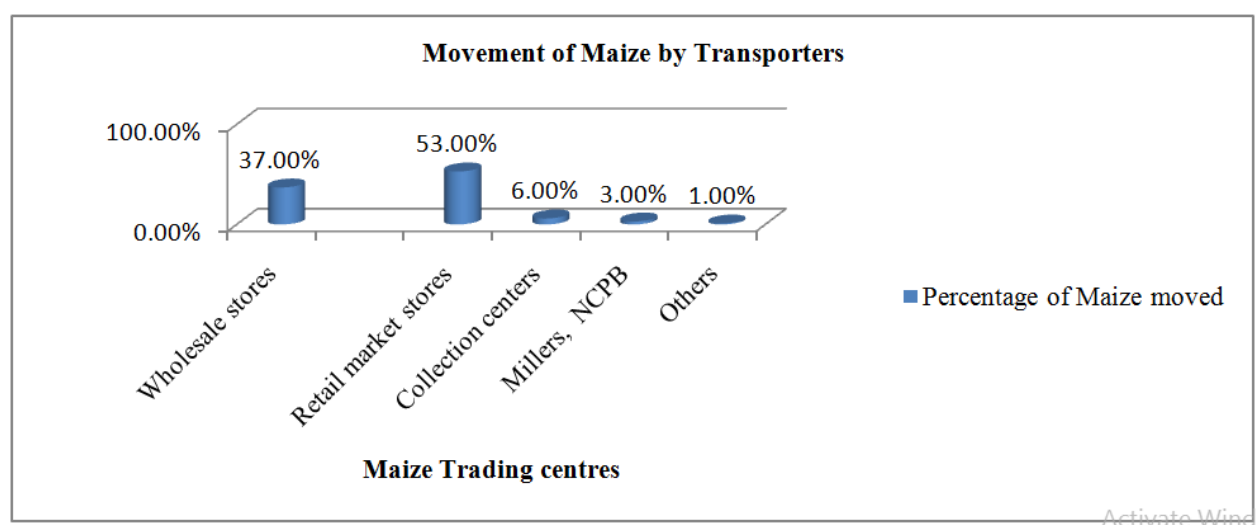

Figure 8 Movement of maize produce by transporters

Study findings reveal that most of the maize from the farmers is transported to small retail maize trading shops (53\%) while only $37 \%$ goes to wholesalers, $6 \%$ to collection points, $3 \%$ to NCPB \& Millers and $1 \%$ to indefinite destinations as shown in Fig 8 . These findings indicate that most of local maize trading is on small scale retail level. This could be due to low yields produced and or lack of money amongst the residents in the region forcing most of traders to do their businesses on small scale level.

\subsection{Level of Business Knowledge amongst the maize traders in the Maize Value Chain}

The respondents were interviewed on various business related issues in order to establish how knowledgeable were the traders in their maize businesses which included of buying and selling dry and green maize, small scale maize "posho" mills, transporting maize. Table 6 represents the findings;

Table 6: Percentage of MVC knowledgeable traders

\begin{tabular}{|l|l|l|l|l|l|l|l|l|}
\hline $\begin{array}{l}\text { Traders with } \\
\text { knowledge of the } \\
\text { basics in the } \\
\text { business }\end{array}$ & $\begin{array}{l}\text { Source of } \\
\text { maize }\end{array}$ & $\begin{array}{l}\text { Market } \\
\text { for the } \\
\text { maize }\end{array}$ & $\begin{array}{l}\text { Transport } \\
\text { ation } \\
\text { modes }\end{array}$ & $\begin{array}{l}\text { Product quality } \\
\text { requirement }\end{array}$ & $\begin{array}{l}\text { Cost of } \\
\text { production for } \\
\text { each unit of } \\
\text { sale }\end{array}$ & $\begin{array}{l}\text { Business } \\
\text { Licenses }\end{array}$ & $\begin{array}{l}\text { Business } \\
\text { records } \\
\text { well kept }\end{array}$ & $\begin{array}{l}\text { Average } \\
\text { contribution as } \\
\text { MVC players }\end{array}$ \\
\hline Count & 33 & 33 & 33 & 23 & 15 & 23 & 20 & \\
\hline Row N\% & $97.1 \%$ & $97.1 \%$ & $97.1 \%$ & $67.65 \%$ & $34.12 \%$ & $37.65 \%$ & 18.82 & $67.07 \%$ \\
\hline
\end{tabular}

Findings revealed that although the traders/transporters in the Maize Value Chain seemed to do their business on small scale, $67.07 \%$ of them are knowledgeable in their businesses as indicated in table 6 above. However, only $18.82 \%$ keep good business records, $37.65 \%$ have their businesses well registered and $34.12 \%$ knew the cost of production of maize although they were trading in it. This could be due to low level of education as most of them went upto primary and secondary levels as shown in table 6, ignorance or poor governance in enforcing business requirements. This implies that maize business in the county is not taken seriously considering how important maize is the county.

\subsubsection{Sources of Finance for Running Maize Businesses}

The study sought to establish where the maize value chain actors get their financing for the maize business operations and figure 5.9 below represents the findings;

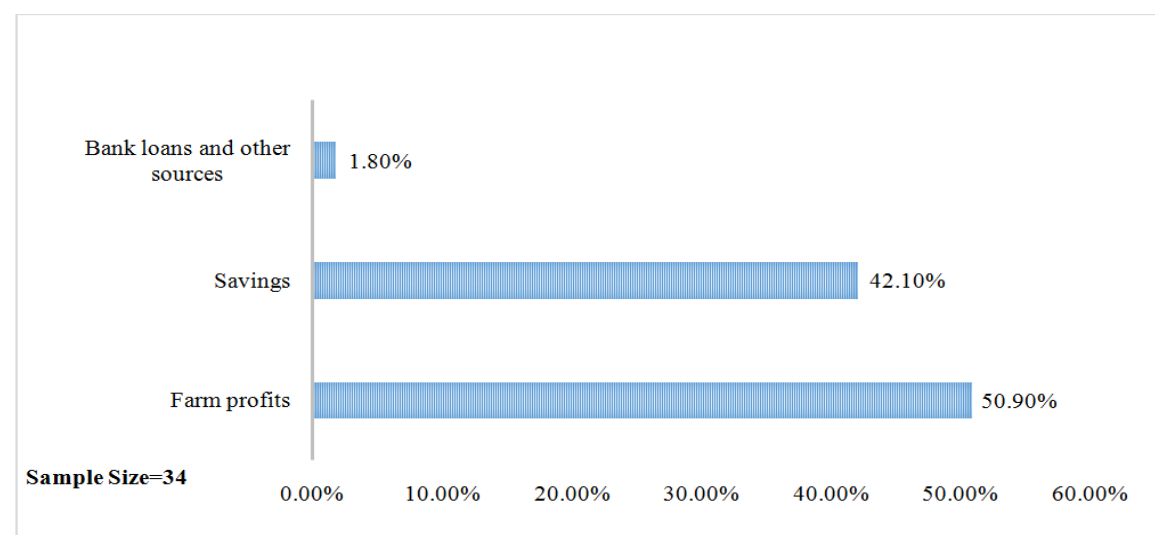

Figure 9: Sources of financing maize businesses 
Fig. 9 shows that most maize businesses in the region finance their operations using their savings and business profits. Noting that most local businesses are small scale, then their savings and profits must also be small indicating that they are not sustainable. It also means that target population is risk averse and that is why they are not going for commercial loans and continue lacking adequate business capital. This calls for the chain enablers to create and govern business environment that enhances agricultural business development and maize stakeholder partnership development for more investment in the maize value chain.

\subsubsection{Main challenges facing Transporters/traders in the region}

The study sought to know if the traders face any challenges in the maize businesses and Fig 10 portrays the findings:

\section{MAIN CHALLENGES FACING MAIZE TRADERS IN BUNGOMA COUNTY}

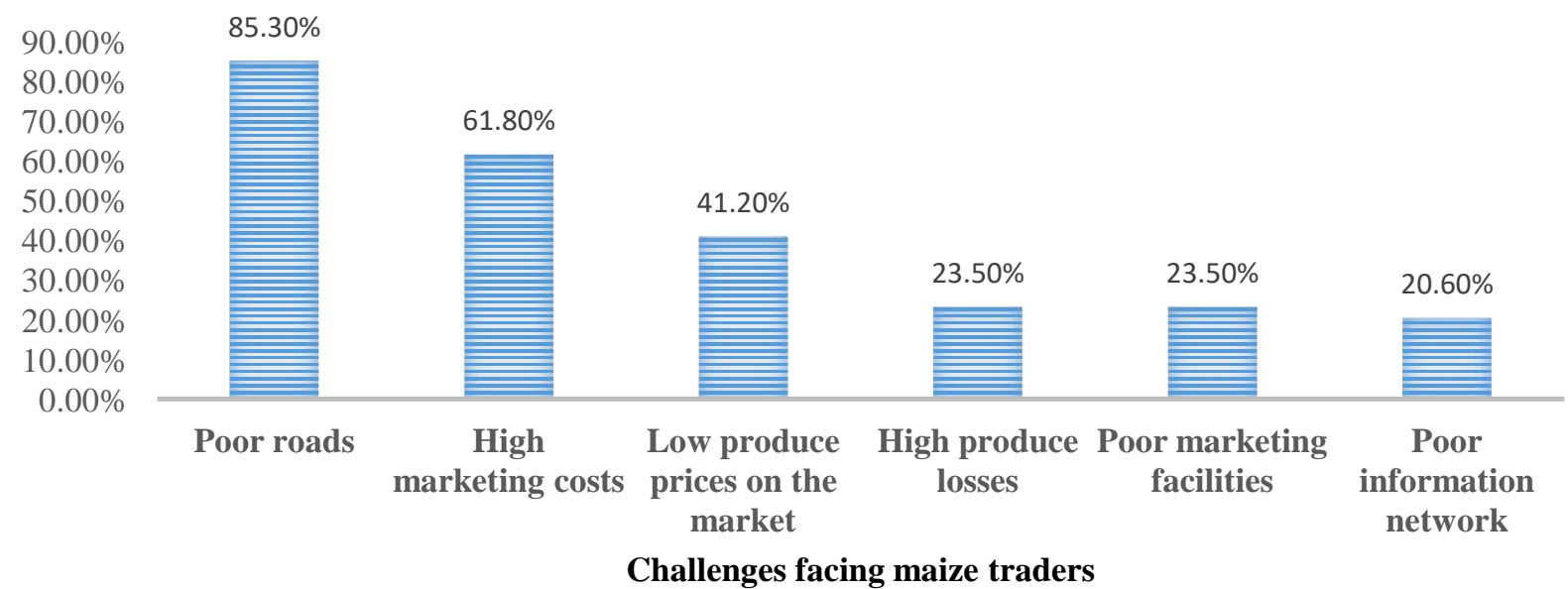

Figure 10 Main challenges facing traders in the region

Poor road system and high marketing costs in Bungoma County were identified as some of the major challenges affecting maize traders in the region as represented by $85.3 \%$ and $61.8 \%$ responses respectively in Fig 10. This calls for improved governance that can bring together maize business stakeholder for identification of business investment opportunities along the maize value chain.

\section{Conclusion}

Approximately $86.24 \%$ of the people in the County depend on maize for their livelihood, food security is at about $35 \%$ and poverty level is $55.5 \%$. It was further revealed that lack of food is the highest indicator that defines the level of the poverty in the region. Poverty level in the region is high at $53.15 \%$, a clear indicator that maize production in the region is not enough to support the livelihood of the people in the community. It can be recalled that all the players in the Maize Value Chain (MVC) suggested that an effective MVC development can help improve on the food security situation in the region and thus reduction the high poverty levels among the people in the community. Value chain development concept is in line with Kenya's Vision 2030 strategy which calls for multi-sectoiral and partnership development approach and is anchored on the economic, social, and political and environment protection pillars, thus being a sustainable development concept Therefore, if value chain approach is embraced it would promote stakeholder participation, facilitation, partnerships, and sustainability would help resolve the many challenges affecting the maize business in the community and hence increased food security and poverty reduction would be achieved. Further, value chain development approach would provide insights into means of acquiring business assets at the level of smallholder households and the local smallholder maize enterprises that are necessary for linking them with downstream chain actors. However, value chain approach for development requires complementary programs aimed at economic growth, such as improvements in local infrastructure and services, political-legal frameworks, local markets for agricultural and forest products, and income generation through services and off-farm employment. That is why there must be mobilization and sensitization of stakeholders for participation, facilitation and development of partnerships 


\section{Acknowledgements}

Professor Wakhungu of Centre for Disaster and Humanitarian Assistance for practical field sampling and data collection on maize value chain development. Jacob Ong'ala of KALRO for data analysis and Dr. Humphrey Nyongesa of Masinde Muliro University of Science and Technology (MMUST) for valuable comments

\section{References}

[1] FAO. (2012). The multiple dimensions of food security

[2] ASDS. . Agriculture Sector Development Strategy (ASDS) (2012). 2010-2020

[3] Anderson, J.R \& Fedder, G. Agricultural Extension: Good intentions and hard realities. The World Bank Research Observer (2004).

[4] GOK.. Bungoma County Integrated Development Plan. (2013). 2013-2017.. Nairobi, Kenya: Government Printers.

[5] Grow Africa. Maize Value Chain Partnership (2014).

[6] BCIDP. Bungoma County Integrated Development Plan (2013). 2013-2017

[7] Ali-Olubandwa .A.M. Adoption of improved maize production practices among small scale farmers in the agricultural reform era: The case of western province of Kenya. Journal of International Agricultural and Extension Education, (2010). Nairobi

[8] GOK. Kenya Economic Survey Highlights. Ministry of State for Planning National Development and Vision 2030. (2010). Nairobi: Kenya Government Printers

[9] Mary Stella Wabwoba, Jacob Wanambacha Wakhungu, Stanley Omuterema. Household Food Insecurity Coping Strategies in Bungoma County, Kenya. International Journal of Nutrition and Food Sciences.Vol. 4, No. 6, (2015), pp. 713-716. doi: 0.11648/j.ijnfs.20150406.28 Kenya Food Security Steering Group (2008). Food Security in Kenya

[10] KARI. Ministry of Agriculture, Livestock and Fisheries and Agricultural Sector Development Strategy Programme (ASDSP), Household Baseline Survey, Bungoma, County Nairobi, Kenya: (2013). Government Printers

[11] Muyanga M. \&T. S. Jayne. Agricultural Extension in Kenya: Practice and Policy Lessons Tegemeo Institute of Agricultural Policy and Development, (2006). Egerton University, Nairobi

[12] IFAD (International Fund for Agricultural Development). (2013). IFAD's Private Sector Development and partnerships Strategy

[13] JADEE. Emerald Journal of Agribusiness in Developing and Emerging Economies (2010)

[14] FAO. State of Food Insecurity in the World (2013). - www.fao.org/publications/sofi/en - Retrieved on 04/09/2014

[15] Syngenta Foundation for Sustainable Agriculture (SFSA) Agricultural extension (2014). - www.syngentafoundation.org/Retrieved on $3 / 02 / 15$ 